\title{
Nutritional evaluation of varying levels of cooked flamboyant seed meal (Delonix regia) on the growth performance and body composition of Nile tilapia (Oreochromis niloticus) fingerlings
}

\author{
Gabriel Gana Bake*, Elizabeth Itunu Martins, Suleiman Omeiza Eku Sadiku \\ Department of Water Resources, Aquaculture and Fisheries Technology, School of Agric and Agric Technology, Federal University of \\ Technology Minna Minna Niger state, Nigeria
}

\section{Email address:}

gabbygana@futminna.edu.ng (G. G. Bake)

\section{To cite this article:}

Gabriel Gana Bake, Elizabeth Itunu Martins, Suleiman Omeiza Eku Sadiku. Nutritional Evaluation of Varying Levels of Cooked Flamboyant Seed Meal (Delonix Regia) on the Growth Performance and Body Composition of Nile Tilapia (Oreochromis Niloticus) Fingerlings. Agriculture, Forestry and Fisheries. Vol. 3, No. 4, 2014, pp. 233-239. doi: 10.11648/j.aff.20140304.14

\begin{abstract}
A feeding trial was conducted to evaluate the effect of inclusion level of cooked Delonix regia seed meal (CDRM) in the practical diet of Oreochromis niloticus fingerlings through their growth performance and nutrient utilization for 56 days. Four iso-nitrogenous and iso-lipidic experimental diets were formulated to contain $35 \%$ crude protein and 9.5\% lipid, CDRM was included at different varying inclusion levels viz: $0,10,15$ and 20 and were designated as D1 (0\% inclusion), D2 (10\% inclusion), D3 (15\% inclusion) and D4 (20\% inclusion). Each treatment was allocated to three tanks of twenty $O$. niloticus per tank with initial mean weight of $1.18 \pm 0.10 \mathrm{~g}$. There was no significant difference $(P>0.05)$ in the survival rate of all the treatments, D2 has the highest value in percentage weight gain, specific growth rate, feed intake, protein efficiency and protein retention, while D4 (20\% inclusion) had the lowest value in all the growth parameters and feed utilization measured. However, there is no significant difference ( $\mathrm{P}>0.05)$ between fish fed D3 $(15 \%$ inclusion) and D1 (control: 0\% inclusion). Proximate composition result revealed that increase in the inclusion level of cooked Delonix regia lead to an increase in carcass lipid content and a decrease in the moisture content of the fish fed experimental diet. The results indicate 10-15\% inclusion of Delonix regia seed meal improved growth performance and nutrient utilization of Nile tilapia fingerlings.
\end{abstract}

Keywords: Delonix Regia Seed Meal, Nile Tilapia, Growth Performance

\section{Introduction}

In order to sustain the consistent expansion being witnessed in aquaculture sector worldwide, a matching increase in fish feed production is imperative (Francis et al., 2001). In finfish aquaculture aqua feed production accounts for between $40-65 \%$ of total operating costs, depending on the level of aquaculture intensification. (Jauncey and Ross, 1982; Hardy 1989 Lovell, 1989). Protein is the most critical and costly ingredient in aqua feed production feeds and usually protein sources represent about $60 \%$ or more in the cost of the feed. Traditionally, fishmeal is preferred dietary protein source for many farmed fish and is appreciated for its amino acid balance, vitamin content, palatability and unidentified growth factors (Tacon, 1993). However, limited supply, increasing demand and high price of fish meal are challenges to the sustainable development of fish culture industry. Wider use of more economical plant or animal protein ingredients is needed for the formulation of costeffective and eco friendly aquafeeds. Several studies focused on assessing the potential to reduce fish meal level in fish diets in the last two decades Bureau et al. 2000; Kureshy et al. 2000; Webster et al. 2000; Milliamena 2002; Gaylord \& Rawles 2005; Wang et al. 2006; Guo et al. 2007). The magnitude of fish meal replacement by economical protein sources varies greatly in literatures because of great variability of fish meal and protein levels used in the basal (control) diets, as well as great variability of chemical composition and nutritive value of the alternate protein ingredients (Ali, et al., 2003; Bureau, et al. 2000; 
Bake, et al 2009). Furthermore, considerable emphasis has been focused on the use of conventional plant protein sources, such as soybean (Nyirenda et al., 2000; Koumi et al., 2009), groundnut (Ovie and Ovie 2007), cotton seed (Mbahinzireki et al., 2001; El-Saidy and Gaber, 2003) and rapeseed meal (Burel et al. 2000a,b), however, their scarcity and competition from other sectors for these conventional crops for livestock and human consumption as well as industrial use make their costs too high and put them far beyond the reach of fish farmers or producers of aquafeeds (Fasakin et al., 1999). Therefore, in order to attain a more economically sustainable, environmentally friendly and viable production, research interest has been redirected towards the evaluation and use of unconventional protein sources, particularly from plant products such as seeds, leaves and other agricultural byproducts (Siddhuraju and Becker, 2001; Olvera-Novoa et al., 2002; Ali, et al., 2003; Bake et al 2009).

Delonix regia a wild plant otherwise called flame of the forest originated from America (Madagascar) but found wild or as ornamental plants in various parts of the world including Nigeria (Purseglove 1994). It is an ornamental, leguminous plant, which produces tones of pods containing seed in the fruiting season (Keay and Stanfield, 1964). These seeds are left unutilized since they are neither consumed by any animal nor utilized for any other medical purposes. Delonix regia (Caesaipincidae) is a tree, which is about $12 \mathrm{~m}$ high with a slightly flat or curving crown. Seeding is abundant and germination is free. The flowers are usually red but sometimes bear a paler orange red flower and flowering is spontaneous, it is one of the most spectacular flowering trees of the tropics. It is widely grown ornamental leguminous plant, which produces 25$40 \mathrm{~cm}$ long pods containing seed which laboratory analysis has reported to contain crude protein $36.92 \%$, crude lipid $4.17 \%$, crude fiber $11.39 \%$ (Grant et al, 1991). Report also showed that the seed extracted exhibited low haemagglutinin activity and contains non-toxic lectins. Flamboyant seed meal compare favorably with mechanically extracted groundnut cake meal in term of crude protein content (NRC, 1993). Heat treatment is employed to dry certain plant product and to improve quality of pelletized feed. Hence, heat treatment can improve the nutritional value of Delonix regia by reducing the hydrocyanic acid and other anti-nutritional factor.

Tilapia is the second most culture fresh water finfish. It is also a common fish in tropical fish farms and its prolific breeding abilities makes it to dominate most ponds and water bodies where the population is not checked. Tilapias are voracious diurnal feeders. Currently, farmed tilapia represents more than $75 \%$ of world tilapia production (FAO, 2006). The high exponential growth of tilapia culture in recent years could be attributed to several factors such as their ability to be grown year round with some variability in fish yields depending upon seasonal differences related to the area (Green et al., 1990). It also effectively utilizes alternative feed ingredients such as rice, cocoa, various flours, and soya-nut oil (Jackson et al., 1982 Brown, 1983). Intensification of tilapia culture requires development of suitable feeds for both complete and supplementary feeding in tanks and ponds (Koprucu and Ozdemir 2005). Therefore, this present study was carried out to evaluate the effect and suitability of cooked flamboyant seed meal (Delonix regia) inclusion in the practical diet of Nile tilapia fingerlings through their growth performance and nutrient utilization.

\section{Materials and Methods Diet Formulation and Preparation}

\subsection{Soybean Meal}

Soybean was obtained from the market and was toasted using a frying pan and allowed to cool before milling with the aid of a grinding machine. Cooking was done to remove the anti-nutritional factor present in the seed.

\subsection{Cooked Flamboyant Seed Meal (Delonix Regia)}

Mature and dried Flamboyant seedpods were collected from the ornamental garden of the Center for Preliminary and Extra Moral Studies (CPES) of the Federal University of Technology Minna; the seed were collected by manually opening the pods. The seeds were boiled at $100^{\circ} \mathrm{C}$ for 80 mins to reduce the effect of hydrocyanic acid (antinutritional factor) and were allowed to cool by sun drying and were later grounded to homogeneous powder.

\subsection{Fishmeal}

The fishmeal used for these experiments was obtained from the market store. The crude protein and lipid content of fishmeal were $61.25 \%$ and $11.94 \%$.

All the ingredients were separately milled and mixed with warm water to form consistent dough, which was then pelleted, sun-dried, packed in polyethylene bags and stored. The feed composition table is shown in Table 1

Table 1. Proximate composition of dietary ingredients diets.

\begin{tabular}{lllllll}
\hline Ingredients & $\begin{array}{l}\text { Fish } \\
\text { meal }\end{array}$ & $\begin{array}{l}\text { Soybean } \\
\text { meal }\end{array}$ & $\begin{array}{l}\text { Raw } \\
\text { D.regia } \\
\text { meal }\end{array}$ & $\begin{array}{l}\text { Cooked } \\
\text { D.regia } \\
\text { meal }\end{array}$ & $\begin{array}{l}\text { Maize } \\
\text { meal }\end{array}$ & $\begin{array}{l}\text { Millet } \\
\text { meal }\end{array}$ \\
\hline $\begin{array}{l}\text { Moisture (\%) } \\
\text { d.b }\end{array}$ & 6.21 & 4.57 & 3.74 & 3.24 & 5.09 & 5.63 \\
$\begin{array}{l}\text { Crude } \\
\text { protein(\%) d.b } \\
\text { Lipid (\%) d.b }\end{array}$ & 10.70 & 7.04 & 4.60 & 7.30 & 4.20 & 3.56 \\
$\begin{array}{l}\text { Ash (\%) d.b } \\
6.69\end{array}$ & 4.35 & 8.79 & 6.48 & 3.84 & 3.60 \\
\hline
\end{tabular}

*1 Dry basis

\subsection{Experimental Diets}

Based on the nutritional requirements of tilapia (NRC 1993), four isonitrogenous and isolipid diets were formulated at $35 \%$ protein and $9.5 \%$ lipids, containing 10 $30 \%$ toasted flamboyant seed meal of different levels of 
inclusion Table 2. The experimental diets were designated D1 (0 \% inclusion), D2 (10\% inclusion), D3 (15\% inclusion) and D4 (20\% inclusion).

Table 2. Formulation and proximate composition of the experimental diets for Oreochromis niloticus fingerlings.

\begin{tabular}{lcccc}
\hline Ingredients & D1 & D2 & D3 & D4 \\
\hline Fishmeal & 384.70 & 345.40 & 325.70 & 302.70 \\
Soybean meal & 220.00 & 220.00 & 220.00 & 220.00 \\
Cooked delonix & 0.00 & 100.00 & 150.00 & 200.00 \\
regia meal & 47.00 & 47.00 & 47.00 & 47.00 \\
Maize meal & 47.00 & 47.00 & 47.00 & 47.00 \\
Millet & 107.90 & 55.00 & 55.00 & 55.00 \\
Starch & 25.50 & 25.50 & 25.50 & 25.50 \\
Vitamin premix & 30.00 & 30.00 & 30.00 & 30.00 \\
Mineral & 30.00 & 30.00 & 30.00 & 30.00 \\
Soybean oil & 107.90 & 100.10 & 69.80 & 42.80 \\
Cellulose & 1000.00 & 1000.00 & 1000.00 & 1000.00 \\
Total & 5.25 & 5.00 & 4.92 & 4.81 \\
Moisture & 34.35 & 36.78 & 36.11 & 34.34 \\
Crude protein & 9.48 & 9.24 & 9.51 & 9.34 \\
Lipid & 10.83 & 10.12 & 9.92 & 9.88 \\
Ash & & & & \\
\hline
\end{tabular}

\subsection{Experimental System and Fish}

The experimental fish, pure- bred $O$. niloticus fingerlings, with a initial mean weight of $(1.19 \pm 0.03)$ were purchased from Tagwai Fisheries hatchery, Ministry of Livestock and Fisheries, Minna, Niger state. The fish were transferred in a well-oxygenated water plastic container from hatchery to the Department of Water Resources, Aquaculture and Fisheries Technology laboratory, Federal University of Technology, Minna where the feeding trial was conducted. Upon arrival they were acclimatized in a transitional tank in the laboratory for four days and were fed commercial feed (coppense feed) at $35 \%$ crude protein once a day before the experiment commenced.

Fresh filtered dechlorinated tap water was supplied to the flow-through system, which consisted of 15-rounded plastic tank, each with an approximate capacity of 45 liter at the flow rate of $250-300 \mathrm{ml} / \mathrm{min}$. The water quality parameters in the system were monitored weekly, and the ranges were dissolved oxygen 6.8-7.4 $\mathrm{mg} / \mathrm{l}$, total ammonia 0.1-0.27 mgN/1, and $\mathrm{pH}$ 6.9-7.5. No critical values were detected for nitrite and nitrate.

Three replicates of each treatment using 20 fish per plastic tank were reared on each of the four experimental diets. Feed was manually administered. The fish were fed three times daily at 5\% of body weight at 0900, 1200 and 1600 hours. Feeding rate were subsequently adjusted according to their growth rates per plastic tank.

The uneaten and faecal matters were siphoned out of tank every morning before feeding, and 45 minutes after the fish have been fed. The fish were denied feed $24 \mathrm{~h}$ prior to sampling. Ten fish were randomly sampled on weekly basis, and weights were measured using a digital electronic weighing balance.

\subsection{Biochemical Analysis}

About $15 \mathrm{~g}$ initial sample and $10 \mathrm{~g}$ of final samples from each plastic tank were pooled separately and then homogenized using laboratory mortal and pestle. The major ingredient used for the diet; the formulated diet and the fish body samples were subjected to chemical analysis. Proximate composition analyses were performed according to AOAC procedures (AOAC, 2000). Moisture content was determined by drying samples at $105 \pm 2{ }^{\circ} \mathrm{C}$ until a constant weight was obtained. Dried samples were used for determination of crude fat, protein and Ash contents. Crude fat was measured by solvent extraction method in a soxhlet system where n-hexane was used as solvent. Crude protein content was calculated by using nitrogen content obtained by Kjeldahl method. A conversion factor of 6.25 was used for calculation of protein content (AOAC, 2000).

\subsection{Evaluation of Growth Parameters}

Growth performance and nutrient utilization were analyzed in terms of weight gain (WG), feed efficiency (FE), specific growth rate (SGR), feed intake (FI), protein efficiency (PER) and protein retention (PR). The following formulas were usedas described by Takeuchi, (1988) as the following equation:

Weight gain $(\%)=($ final weight $(g)-$ initial weight $(g) x$ 100 / initial weight $(\mathrm{g})$

Feed efficiency $(\%)=($ weight gained $(\mathrm{g}) /$ feed fed $(\mathrm{g})) \mathrm{x}$ 100

Specific growth rate $(\%)=($ In final weight $(g)-$ In initial weight (g) / feeding period (day) x 100

Feed intake $(\mathrm{mg} /$ fish/day) = dry feed $(\mathrm{mg})$ given / number of fish / feeding period (day)

Protein efficiency ratio $=$ wet body gain $\mathrm{x} 100 /$ protein intake $(\mathrm{g})$

Protein retention $(\%)=$ protein gain $\times 100 /$ protein fed.

\subsection{Statistical Analyses}

Data were analyzed using one - way analysis of variance (ANOVA) using Statistica 6.0 (Stat-Soft, Inc., USA). Differences between treatments were compared by Tukey's test. Level of significance was tested at $\mathrm{P}<0.05$.

\section{Results}

The proximate composition of the major ingredients used in the formulation of the experimental diet is shown in Table 1. Fishmeal had the highest crude protein and lipid contents (61.25 and 10.70\%) followed by soybean meal (43.07 and 7.0\%) while cooked Delonix regia meal had 25.11 and $8.30 \%$ of crude protein and lipid contents, respectively. Though all the experimental diets were similar in terms of their proximate composition among the experimental diets, D2 had the highest crude protein content of $36.93 \%$ while diet 4 had the lowest crude protein content of $34.34 \%$. The total lipid was highest in diet 3 (9.51\%) while diet 2 had the lowest total lipid content 
(9.24\%). Ash content was highest in diet 1(10.83\%) and lowest in diet $4(9.88 . \%)$ among the test diets (table 2).

There was no feed rejection among the fish fed experimental diets; however the acceptability of the diets differed considerably among the treatments. Table 3 showed that Tilapia fed with $10 \%$ inclusion of cooked Delonix regia meal (D2) had the highest final body weight gain, specific growth rate, and total feed intake and was significantly higher than the rest of the treatments $(P<0.05)$ while tilapia fed with $20 \%$ inclusion of cooked Delonix regia meal (D4) had the lowest significant value in all the growth parameters measured. The growth parameter values measured for tilapia fed D1 and D3 were not significantly different from each other but were significantly higher than tilapia fed D4 $(P<0.05)$.

Fish fed with D2 had the highest significant value $(P<0.05)$ feed efficiency, Protein efficiency ratio and protein retention. Although fish fed D4 had the lowest feed efficiency and protein efficiency ration, it was not significantly different from fish fed D1 and D3 $(P>0.05)$ however the protein retention of tilapia fed D1 and D3 was significantly higher $(P<0.05)$ than those fed D4.

Variations in the tilapia body composition among fish fed experimental diets at the end of the feeding trial are shown in Table 4.The result of the body composition revealed that except for lipid and moisture fish fed cooked Delonix regia meal displayed a marginal increase in the carcass proteinand ash at the end of the experiment and were significantly higher than the initial body composition at the start of the experiment. There was no significant differences in the carcass ash contents among all the treatments fed experimental diets, fish fed D2 having the highest crude protein content value and was significantly higher than the other fish fed other experimental diet $(P<0.05)$, however fish fed D1, D3 and D4 do not show any significant difference $(P>0.05)$ from each other. Fish fed D4 had the highest significant lipid composition $(P<0.05)$ while D1 had the lowest value but was not significantly different from fish fed D2. Fish fed D1 showed the highest moisture among the experimental diets although not significantly different from D2 $(P<0.05)$ but were significantly different from D3 and D4.

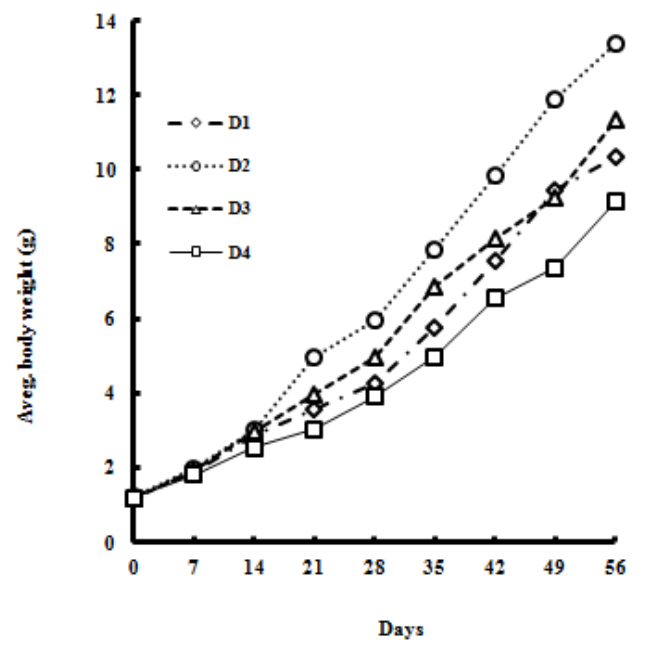

Fig 1. Growth of O.niloticus fingerlings fed the experimental diets for 56 days.

Table 3. Growth performances of $O$. niloticus fry fed experimental diets for 56 days.

\begin{tabular}{|c|c|c|c|c|c|c|c|c|c|}
\hline \multirow{2}{*}{$\begin{array}{l}\text { Diet } \\
\text { code }\end{array}$} & \multicolumn{2}{|c|}{ Body weight (g) } & \multirow{2}{*}{ Weight gain (\%) } & \multirow{2}{*}{$\begin{array}{c}\text { Survival rate } \\
(\%)\end{array}$} & \multirow{2}{*}{$\begin{array}{c}\text { Specific } \\
\text { growth rate } \\
(\%)\end{array}$} & \multirow{2}{*}{$\begin{array}{l}\text { Total feed } \\
\text { intake (g) }\end{array}$} & \multirow{2}{*}{$\begin{array}{c}\text { Feed } \\
\text { efficiency }\end{array}$} & \multirow{2}{*}{$\begin{array}{c}\text { Protein } \\
\text { efficiency } \\
\text { ratio } \\
\end{array}$} & \multirow{2}{*}{$\begin{array}{c}\text { Protein } \\
\text { retention }(\%)\end{array}$} \\
\hline & Initial & Final & & & & & & & \\
\hline D1 & $1.21 \pm 0.04$ & $10.32 \pm 0.01^{\mathrm{b}}$ & $932.00 \pm 12.00^{b}$ & $97.30 \pm 0.74^{\mathrm{a}}$ & $3.83 \pm 0.01^{\mathrm{bc}}$ & $11.56 \pm 0.10^{b}$ & $0.79 \pm 0.01^{\mathrm{c}}$ & $2.28 \pm 0.03^{b}$ & $35.93 \pm 0.44^{b}$ \\
\hline D2 & $1.20 \pm 0.07$ & $13.40 \pm 0.43^{\mathrm{a}}$ & $1240.00 \pm 43.59^{\mathrm{a}}$ & $98.22 \pm 0.42^{\mathrm{a}}$ & $4.31 \pm 0.04^{\mathrm{a}}$ & $12.63 \pm 0.10^{\mathrm{a}}$ & $0.97 \pm 0.04^{\mathrm{a}}$ & $2.60 \pm 0.06^{\mathrm{a}}$ & $41.97 \pm 0.91^{\mathrm{a}}$ \\
\hline D3 & $1.17 \pm 0.06$ & $11.32 \pm 0.54^{\mathrm{b}}$ & $1032.67 \pm 54.72^{b}$ & $97.68 \pm 0.57^{\mathrm{a}}$ & $4.05 \pm 0.06^{\mathrm{b}}$ & $11.65 \pm 0.72^{b}$ & $0.87 \pm 0.01^{\mathrm{bc}}$ & $2.39 \pm 0.03^{\mathrm{b}}$ & $36.70 \pm 0.51^{\mathrm{b}}$ \\
\hline D4 & $1.18 \pm 0.02$ & $9.13 \pm 0.64^{\mathrm{c}}$ & $812.33 \pm 64.33^{c}$ & $97.12 \pm 1.05^{\mathrm{a}}$ & $3.41 \pm 0.08^{\mathrm{c}}$ & $10.47 \pm 0.84^{\mathrm{c}}$ & $0.75 \pm 0.01^{\mathrm{c}}$ & $2.14 \pm 0.04^{\mathrm{b}}$ & $33.33 \pm 0.69^{c}$ \\
\hline
\end{tabular}

*1 Values in the same column with different superscript letters are significantly different $(p<0.05)$ from each other.

Table 4. Proximate composition analyses of whole body O. niloticus (wet basis) fed experimental diets for 56 days

\begin{tabular}{|c|c|c|c|c|c|}
\hline \multirow{2}{*}{ Component (\%) } & \multirow{2}{*}{ Initial } & \multicolumn{4}{|c|}{ Final $^{* 1}$} \\
\hline & & D1 & D2 & D3 & D4 \\
\hline Moisture & 75.64 & $74.25 \pm 1.5^{\mathrm{a}}$ & $73.56 \pm 1.3^{\mathrm{ab}}$ & $72.75 \pm 0.3^{c}$ & $72.62 \pm 1.4^{c}$ \\
\hline Protein & 14.94 & $15.39 \pm 1.3^{\mathrm{bc}}$ & $16.09 \pm 1.7^{\mathrm{a}}$ & $15.67 \pm 1.1^{\mathrm{b}}$ & $15.46 \pm 1.5^{b}$ \\
\hline Lipid & 5.19 & $5.08 \pm 0.4^{\mathrm{c}}$ & $5.03 \pm 0.6^{c}$ & $6.28 \pm 0.5^{\mathrm{b}}$ & $6.68 \pm 0.2^{\mathrm{a}}$ \\
\hline Ash & 4.63 & $5.15 \pm 0.6^{\mathrm{a}}$ & $5.05 \pm 0.4^{\mathrm{a}}$ & $5.22 \pm 0.1^{\mathrm{a}}$ & $5.16 \pm 0.4^{\mathrm{a}}$ \\
\hline
\end{tabular}

$* 1$ Values in the same row with different superscript letters are significantly different $(\mathrm{p}<0.05)$ from each other $(\mathrm{n}=3)$.

\section{Discussion}

This study investigated the possibility of utilizing cooked Delonix regia meal in the diet of $O$. niloticus fingerlings. Fish mortality was low and relatively uniform in all the treatments, furthermore all the experimental fish remaining in the tanks were morphologically normal at the end of the feed trial. In our study, the water temperature which ranged between between $25 \pm 0.5^{\circ} \mathrm{C}-29 \pm 0.4^{\circ} \mathrm{C}$ and the dissolved oxygen $6.6-8.3 \mathrm{mg} / \mathrm{L}$ were within the acceptable range for tilapia culture (Balarin and Halton, 1979). 
The proximate composition of cooked Delonix regia meal in this present study revealed that the crude protein content was $25.11 \%$ (Table 2). This value was higher than the values reported earlier by Balogun et al.(2004). The differences might be attributed to differences in environmental conditions such as soil types, harvesting time and the processing conditions. Fagbenro (1999), Francis et al. (2001) and Solomon et al. (2007) reported that heat treatment substantially reduces and inactivates levels of secondary compounds in the seed meals. Our results tend to agree with their report.

The suitability of inclusion of alternative ingredient in a fish diet in terms of growth performance has been reported to vary highly among fish species and experimental conditions (El-Sayed 1999, Bake et al.2009). The percentage survival was excellent throughout the experimental period. This could be attributed to good handling, good water quality management and proper processing and the suitability of cooked Delonix regia meal inclusion in the diet of $O$. niloticus. However within the conditions of this experiment, cooked flamboyant seed meal (Delonix regia) was acceptable source of protein in the diets of $O$.niloticus fingerlings. The fishes adapted to the diets within 3-4 days of commencement of feeding trial, however the acceptability of the diet varied significantly. Table 3 and Figure 1 showed that acceptability of the diet reduced with the increase in the inclusion level of cooked flamboyant seed meal. The slight lower growth response by tilapia fed 20\% cooked Delonix regia meal (D4) inclusion can be attributed to reduced palatability of the diet, which could be as a result of low feed intake. The best growth responses were obtained with tilapia fed (D2) $10 \%$ inclusion of cooked Delonix regia. Although, there was no significant difference between fish fed D1 and D4. Proper processing of ingredients has been reported to have effect on the texture, palatability and taste of experimental diets and are related to the level of plant material incorporated, hence can affect the acceptability of feed and may consequently retard growth of the fish when in high quantity (Fagbenro, 1999; Francis et al 2001 and Solomon et al 2007). The high FI obtained in this study may also be ascribed to the cooking processing technique employed in processing of the flamboyant seed. This may have reduced the effect of anti-nutritive factors and other secondary compound activities in the seed. Akinmutimi (2006) reported decrease in crude protein content of Mucuna Pruriens when cooked for 60 minutes; Balogun (2009) reported that boiled Delonix regia seed meal has higher potential of being utilized by $O$. niloticus when boiled for 80 minutes. In our present study cooking of Delonix regia seed meal for 120 minutes at $100^{\circ} \mathrm{C}$ and including it in the diet of Nile tilapia fingerlings at $10-15 \%$ significantly improve their growth performance and nutrient utilization.

Olvera-novoa et al. 2002 reported that when plant proteins are included in the diet of Nile tilapia at 10-20\% they do have better feeding efficiency. Result from our study revealed that the FE, PER and PR decreases with increase in the inclusion level of the cooked delonix regia meal. Although there was no much significant difference between D1, D3and D4, D1 and D3were better than D4.This indicates that D4 has high nutritive content and its low intake may be responsible for low in WG and SGR.

From the result of the proximate composition in Table 4, the total lipid of the fish fed experimental diets is related to the body moisture content and also showed that higherlevel inclusion of cooked Delonix regia seed meal in the diet of Nile tilapia fingerlings as the potential in increasing lipid deposition in its carcass. This result agrees with the findings of Abd El- Hakim et al. (2003) that plant protein in the diet of fish has the potential to increase its lipid deposition in the carcass of the fish fed plant protein.

The present study has demonstrated that the cooking processing method of Delonix regia seed meal as significant effect on the tilapia diet hence can partially inactivate some of the secondary compound in Delonix regia seed meal there by improve its growth performance and feed efficiency. Furthermore, Delonix regia seed meal can be suitable as an ingredient in Nile tilapia diet.

\section{References}

[1] Abdelghany, A. E. (2003). Partial and complete replacement of fishmeal withgambusia meal in diets for red tilapia (Oreochromis niloticus $x$ O.mossambicus). Aquaculture Nutrition9:145-154.

[2] Abd El-Hakim N. F., Hussein M. S. and Abdel-HalimH. A. (2009) Effect ofpartial replacement of soybean meal protein with dehydrated alfalfa meal(Medicago sativa $\mathrm{L}$.) on growth performance and feed utilization of maleNile tilapia (Oreochromis niloticus L.) fingerlings reared in tanks. Egypt J. Aquat. Biol. and Fish., Vol. 13, No. 2:35 - 52.

[3] Ali, A.; Al-Asgah, N.A.; Al-Ogaily S.M. and Ali, S. (2003). Effect of feeding different levels of alfalfa meal on the growth performance and body composition of Nile tilapia (Oreochromis niloticus) fingerlings. Asian. Fish.Soci-16: 12.

[4] Bake, G. G., M. Endo, A. Akimoto and T. Takeuchi (2009) Evaluation of recycled food waste as a partial replacement of fishmeal in the diets for first feeding Nile tilapia Oreochromis niloticus. Fish. Sci., 75, 1275- 1283.

[5] Balarin, J.D. and J.P. Halton, 1979. Tilapia: A guide to their biology and culture in Africa. University of Stirling, Stirling, Scotland, UK.

[6] Balogun, J.K., Abdullahi, S.A., Auta, J. and Ogunlade (2004) Feed conversion, protein efficiency, digestibility and growth performance of Oreochromis niloticus fed Delonix regia meal . $19^{\text {th }}$ Annual conference Processing's of the Fisheries Society of Nigeria (FISON) Pp 823-831.

[7] Borgeson, T. L., V. J. Racz, D. C. Wilkie, L. J. White, and M. D. Drew. (2006). Effect of replacement fishmeal and oil with simple or complex mixtures of vegetable ingredients in diets fed to Nile tilapia (Oreochromis niloticus).Aquaculture Nutrition 12:141-149. 
238 Gabriel Gana Bake et al: : Nutritional Evaluation of Varying Levels of Cooked Flamboyant Seed Meal (Delonix Regia) on the Growth Performance and Body Composition of Nile Tilapia (Oreochromis Niloticus) Fingerlings

[8] Burel, C., Boujard, T., Tulli, F., Kaushik, S.J., 2000a. Digestibility of extruded peas, extruded lupin, and rapeseed meal in rainbow trout (Oncorhynchusmykiss) and turbot (Psetta maxima). Aquaculture 188, 285-298.

[9] Burel, C., Boujard, T., Escaffre, A.M., Kaushik, S.J., Boeuf, G., Mol, K., van der Geyten, S., Kuahn, E.R., 2000b. Dietary low glucosinolate rapeseed meal affects thyroid status and nutrient utilization in rainbow trout (Oncorhynchus mykiss). British Journal of Nutrition 83, 653-664.

[10] El-Saidy, D. M. S. D. and M. M. A. Gaber. (2003). Replacement of fish meal with a mixture of different plant protein sources in juvenile Nile tilapia,Oreochromis niloticus (L.) diets. Aquaculture Research 34:1119-1127.

[11] El-Saidy, D. M. S. D. and M. M. A. Gaber. (2004). Use of cottonseed mealsupplemented with iron for detoxification of gossypol as a total replacement of fish meal in Nile tilapia, Oreochromis niloticus (L.) diets. Aquaculture Research35:859-865.

[12] Fagbenro O. A and Davis S. J, (2003). Use of high percentages soybean protein concentrate as fishmeal substitute in practical diets for African catfish, C. gariepinus (Burchell 1822): growth, feed utilization and digestibility J. Applied Aquac.. 16 (1).

[13] Fapohunda O. O. (2012) Evaluation of Processed Soybean Meal in the Feeding of Clarias gariepinus Fingerlings $J$ Anim Sci Adv, 2(2): 244-249.

[14] Fasakin, E. A., Balogun, A. M., and Fasuru, B. E. (1999). Use of duckweed, Spirodela polyrrhiza L. Schleiden, as a protein feedstuff in practical diets for tilapia, Oreochromis niloticus L. Aquaculture Research 30:313-318.

[15] Francis, G; Makkar, HPS; Becker, K (2001). Antinutritional factors present inplant-derived alternate fish feed ingredients and their effects in fish.Aquaculture, 199, 197227.

[16] FAO. (2007). The State of World Fisheries and Aquaculture (2006). Fisheriesand Aquaculture Department, FAO, Rome, $162 \mathrm{pp}$.

[17] Gaber, M. M. (2006). The effects of plant-protein-based diets supplemented with yucca on growth, digestibility, and chemical composition of Nile tilapia (Oreochromis niloticus, L) fingerlings. Journal of the World Aquaculture Society $37: 74-81$.

[18] Gatlin III, D.M., Barrows, F.T., Brown, P., Dabrowski, K., Gaylord, G.T., Hardy, R.W.,Herman, E., Hu, G., Krogdahl, Å., Nelson, R., Overturf, K., Rust, M., Sealey, W., Skonberg, D., Souza, J.E., Stone, D., Wilson, R., Wurtele, E., (2007). Expanding the utilization of sustainable plant products inaquafeeds: a review. Aquaculture Research 38, 551-579.

[19] Gaylord, T.G. Rawles, S.D., (2005). The modification off poultry by-product meal for use in hybrid striped bass Morone chrysops x M. saxatilis diets. Journalof the World Aquaculture Society 36, 365-376.

[20] Glencross, BD; Booth, M; Allan, GL (2007). A feed is only as good as its ingredients - A review of ingredient evaluation strategies for aquaculture feeds. Aquac. Nutr., 13, $17-34$.
[21] Grant, G., I.J. Moore, N.H. Mckenzie, P.M. Doward, J.C. Stewart, L. Teleck and A.Psuztai, (1991). A Survey of Haemaglutination Properties of Several Tropical Seeds. Livestock Research for Rural Development, 3: 1-7.

[22] Green, B.W., D.R. Teichert-Coddington and P.R. Phelps. (1990). Response of tilapia yield and economics to varying rates of organic fertilization andseason in two Central American countries. Aquaculture 90: 279-290.

[23] Guo, J., Wang, Y. and Bureau, D.P. (2007). Inclusion of rendered animal ingredients as fishmeal substitutes in practical diets for cuneate drum, Nibea miichthioides (Chu, Lo et $\mathrm{Wu}$ ). Aquaculture Nutrition, 13:81-87.

[24] Hardy, R.W., Sullivan, C.V., (1983). Canola meal in rainbow trout Salmogairdneri production diets. Can. J. Fish. Aquat. Sci. 40, $281-286$.

[25] Jauncey, K. and B. Ross. (1982). A Guide to Tilapia Feeds and Feeding. Institute ofAquaculture, University of Stirling, United Kingdom.

[26] Jackson, AJ; Capper BS; Matty AJ (1982). Evaluation of some plant protein in complete dietsfor the tilapia Sarotherodon mossambicus. Aquaculture 27: 97-109.

[27] Koprucu, K. and Ozdemir, C. (2005). Apparent digestibility of selected feed ingredients for Nile tilapia (Oreochromis niloticus). Aquaculture, 250:308-316.

[28] Koumi, A.R., Atse, B.C. and Kouame, L.P., (2009). Utilization of soya protein as an alternative protein source in Oreochromis niloticus diet: Growth performance, feedutilization, proximate composition and organoleptic characteristics. African Journal of Biotechnology, 8(1):091-097.

[29] Kureshy, N., D. A. Davis, and C. R. Arnold. (2000). Partial replacement of fishmeal with meat and bone meal, fl ash dried poultry by-product meal, and enzyme-digested poultry by-product meal in practical diets forjuvenile red drum. North American Journal of Aquaculture 62:266-272.

[30] Mbahinzireki, GB; Dabrowski, K; Lee, KJ; El-Saidy, D; Wisner, ER (2001). Growth, feed utilization and body composition of tilapia (Oreochromis sp.) fed with cottonseed meal-based diets in a recirculating system. Aquac. Nutr.7, 189-200.

[31] National Research Council, (NRC) (1993). Nutrient Requirements of Fish.NationalAcademy Press, Washington, DC, $128 \mathrm{p}$.

[32] Nyirenda, J., Mwabumba, M., Kaunda, E. and Sales, J., (2000). Effect of Substituting Animal Protein Sources with Soybean Meal in Diets of Oreochromis karongae (Trewavas, 1941). Naga, The ICLARM Quarterly, 23(4):13-15.

[33] Ovie S. O., and Ovie S. I. (2007). The effect of replacing Fishmeal with $10 \%$ of Groundnut cake in the diets of $H$. longifilis on its Growth, Food conversion and Survival. J. Appl. Sci. Environ. Manage.Vol. 11(3) 87 - 90.

[34] Purseglove, J.W. (1994) Tropical crops: Dicotyledons. Longman, London, U.K. p 122.

[35] Richter, N., P. Siddhuraju, and K. Becker. (2003). Evaluation of nutritional quality of moringa (Moringa oleifera Lam.) leaves as an alternative protein source for Nile tilapia (Oreochromis niloticus L.). Aquaculture 217:599-611. 
[36] Siddhuraju, P. and K. Becker (2003) Comparative nutritional evaluation of differentially processed mucuna seeds (Mucuna pruriens (L.) DC. var. utilis (Wall ex Wight) Baker ex Burck), on growth performance, feed utilization and body composition in Nile tilapia (Oreochromis niloticus L.). Aquacult. Res.,34, 487-500.

[37] Tacon, A. G. J. (1993). Feed ingredients for warm water fish. Fishmeal and other processed feedstuffs. FAO Fish. Circ. No. 856, FAO, Rome, Italy, 64 pp.

[38] Takeuchi, T. (1988) Laboratory work- Chemical evaluation of dietary nutrients. In:Fish nutrition and Mariculture. JICA Textbook, the General Aquaculture Course. (ed.by T. Watanabe). Kanagawa International Fisheries Training Centre, JapanInternational Cooperation Agency, Tokyo, pp. 179-233.
[39] Tiamiyu, L. O., Solomon, S. G., and Oketa, E. J. (2006). Effects of different boilingtime of soyabean (Glycine Max (L) Merril) on growth performance of tilapia(Oreochromis niloticus) fingerlings. Journal of Aquatic Sciences 21(1): 15-18.

[40] Wang, Y., Guo, J., Bureau, D.P., Cui, Z., (2006). Effects of dietary protein and energy levels on growth, feed utilization and body composition of Cuneate drum, Nibea miichthioides. Aquaculture 252, 421-428.

[41] Webster, C. D., K. R. Thompson, A. M. Morgan, E. J. Grisby, and A. L. Gannam.(2000). Use of hempseed meal, poultry by-product meal, and canola meal in practical diets without fishmeal for sunshine bass (Morone chrysops $x \mathrm{M}$. saxatilis). Aquaculture 188: 299-30. 